\title{
8. The Need for Wellbeing Measurement in Context
}

\author{
David Gruen and Duncan Spender
}

This chapter aims to shed light on both the role of the Treasury wellbeing framework and Treasury's perspective on wellbeing measurement, by focusing on the broad context in which Treasury's wellbeing framework sits.

Treasury can help improve wellbeing without having in its possession a complete, agreed approach to wellbeing measurement.

- The Treasury mission requires us to serve our ministers, and the nature of democracy suggests a positive relationship between the service of ministers and improving societal wellbeing.

- The Treasury wellbeing framework reminds Treasury staff to inform their advice with an understanding that wellbeing is driven by several distinct considerations and that trade-offs will often be required. This assists ministers to make value judgements, taking into account community preferences and hence supporting wellbeing.

- The Treasury wellbeing framework requires us to undertake objective and thorough analysis using the best available tools. Rigorous application of well-worn economic tools provides us with some assurance that the policy recommendations that result are consistent with improving wellbeing.

- Provided that market and government failures are addressed, we can have some confidence that people and businesses going about their lives will tend to improve wellbeing.

Moreover, Treasury's broad wellbeing objective is accompanied by more specific - and more measurable - objectives.

So while efforts to improve and get agreement on wellbeing measures are well worthwhile, public policy agencies like the Treasury can nonetheless carry out their responsibilities in the absence of a complete, agreed approach to wellbeing measurement.

\footnotetext{
1 This chapter is a revised version of an address by the first author to the Economic Growth and Wellbeing Symposium in honour of Ian Castles AO, held by ASSA and the Crawford School at The Australian National University, 22 November 2012. We thank Harry Greenwell, James Kelly, Martin Parkinson, Andrew Podger and Angela Woo for helpful comments on an earlier draft.
} 
This chapter briefly recaps Treasury's consideration of wellbeing and some thoughts on wellbeing measurement, before turning to how Treasury carries out its responsibilities in the absence of an agreed approach to wellbeing measurement. ${ }^{2}$

\section{A longstanding focus on wellbeing}

The idea that public policy should be concerned with both economic growth and broader concepts such as wellbeing is a longstanding one for both the economics profession and Treasury.

The conceptual distinction between welfare/utility and income/output was recognised by the pioneers of the discipline, including Adam Smith and John Stuart Mill. It was further explored by later economists such as Kelvin Lancaster and Gary Becker. ${ }^{3}$

Given this history, it should be no surprise that Treasury has for a long time incorporated both economic growth and wellbeing considerations into its analysis and advice. For example, a 1964 Treasury paper outlined the importance of measured economic activity but noted that a change in the market value of output is nonetheless not a comprehensive or unambiguous measure of the change in total welfare. ${ }^{4}$ Many of the same points were made in the Treasury 1973 paper, 'Economic Growth: Is It Worth Having?' to which Ian Castles made major contributions. ${ }^{5}$ A narrower approach essentially focused on growth in GDP, or in GDP per capita, would represent an overly restrictive lens through which to analyse many of the most important public policy issues.

The Treasury's conception of wellbeing has developed over time, in line with developments in economic thought. The current Treasury wellbeing framework makes clear that Treasury views wellbeing as primarily reflecting a person's substantive freedom, consistent with the relatively recent work of Amartya Sen. ${ }^{6}$ People have substantive freedom if they have the capability to lead a life

\footnotetext{
2 Treasury's wellbeing framework is summarised in the attachment. For a recent detailed discussion of the Treasury wellbeing framework, its history and elements, see Kelly, James and Stephanie Gorecki 2012 'Treasury's Wellbeing Framework' Economic Roundup, Issue 3: 27-64. Issues with the measurement of wellbeing have been discussed in detail in Gorecki, Stephanie, David Gruen and Shane Johnson 2011 'Measuring wellbeing in theory and practice', Treasury Working Paper No. 2011-02, Canberra, and Gruen, David and Joanne Wilkie 2009 'New paradigms to measure progress', Economic Roundup, Issue 4: 1-9.

3 See, for example, the discussion of the conceptual basis for Treasury's Wellbeing Framework in Treasury 2004 'Policy advice and Treasury's wellbeing framework', Economic Roundup, Winter, Canberra: 2-5.

4 Treasury 1964 'The Meaning and Measurement of Economic Growth', Supplement to the Treasury Economic Bulletin, November, Canberra.

5 Treasury Economic Paper No. 2, Canberra.

6 Sen, Amartya 1999, Development as Freedom, Oxford University Press, Oxford.
} 
they have reason to value. As such, substantive freedom depends not just on people's rights and liberties, but on their abilities and characteristics and the economic, social and natural environment around them.

\section{Measuring wellbeing}

Before discussing how Treasury carries out its responsibilities without there being an agreed approach to wellbeing measurement, we briefly recap some general thoughts on such measurement.

Wellbeing measurement is important. In the words of the Sen-Stiglitz-Fitoussi Commission on the Measurement of Economic Performance and Social Progress, 'what we measure affects what we do'. ${ }^{7}$ What we measure affects judgements about the current state of affairs and what policy responses are needed. Policy choices need to be based on both reason and empirical evidence; theory and practice need to work together.

The Treasury wellbeing framework requires staff to use the best available evidence and measures. The Treasury is an intensive and extensive user of measures that, when brought together, give an indication of the wellbeing of the Australian people. Such measures also help to evaluate our performance.

But for the foreseeable future we will continue to face an array of differing approaches to wellbeing measurement, rather than having in our possession a fully agreed approach.

This is the case because a fully agreed approach to wellbeing measurement would require full agreement on the concept of wellbeing itself.

- While there is much agreement as to things that are important to wellbeing, there is no common all-encompassing conceptualisation of wellbeing. Even an individual's conception of his or her own wellbeing can be conflicted, and this conception needs to be examined and aggregated across individuals before we can arrive at an agreed concept of the wellbeing of society.

- The Treasury's wellbeing framework starts with a broad-ranging statement that wellbeing primarily reflects a person's substantive freedom to lead a life they have reason to value. This language reflects a pluralistic approach to understanding wellbeing, drawn as mentioned from the capabilities approach of Amartya Sen. The language doesn't prescribe what it is that is valued, and it doesn't say how to aggregate across individuals.

7 Stiglitz, Joseph, Amartya Sen and Jean-Paul Fitoussi 2009 'Report by the Commission on the Measurement of Economic Performance and Social Progress', Commission on the Measurement of Economic Performance and Social Progress: 7. 
Alongside difficulties arising from conceptual differences, there are also various practical difficulties with wellbeing measurement.

- The measurement of material wellbeing involves significant difficulties with measuring quality and non-market services.

- The measurement of opportunities and capabilities involves attempting to measure what people could do, as opposed to what they actually do. ${ }^{8}$

- The measurement of self-reported subjective wellbeing is complicated by the various types of wellbeing that could be reported (e.g. mood happiness, life satisfaction or feelings of agency and autonomy). ${ }^{9}$

- And the estimation of future wellbeing involves taking a position on (at least) future preferences, discoveries, technological developments, events and population growth.

\section{Serving ministers}

Importantly, the lack of a fully agreed approach to wellbeing measurement does not pose an insurmountable problem for Treasury's use of its wellbeing framework, though it does help to focus on how the framework should be used.

Treasury's main role is to serve the people of Australia through the government of the day. That is, through its role in supporting ministers to discharge their responsibilities. Given the positive relationship between democracy and improving societal wellbeing, public servants in a democratic society should have confidence that serving their ministers, by providing advice and helping to implement policies, tends to improve wellbeing. This is true even if the measurement of wellbeing remains far from perfect.

Given the Treasury's traditional focus on economics, it is worth mentioning that this view of the positive relationship between democracy and wellbeing has strong foundations in economic theory, and is a view shared by economists who otherwise vary considerably in their world view. ${ }^{10}$

For instance, modern public finance theory was born more than a century ago when economists such as the Swedish economist Knut Wicksell directed

8 Measurement is a notorious problem for Sen's capabilities approach to wellbeing (Fleurbaey, Marc 2009, 'Beyond GDP: The Quest for a Measure of Social Welfare', Journal of Economic Literature, 47(4): 1029-1075).

9 Agency in this context refers to the capacity to act with purpose to one's advantage. This capacity is considered to be more important for subjective wellbeing as society becomes richer and basic material needs are met.

10 There is also empirical evidence of a positive relationship between democracy and subjective wellbeing measures, after controlling for economic development and initial subjective wellbeing levels (Inglehart, Ronald, Robert Foa, Christopher Peterson and Christian Welzel 2008 'Development, Freedom, and Rising Happiness: A Global Perspective (1981-2007)’ Perspectives on Psychological Science 3(4): 264-285. 
the recently developed tools of marginal theory towards an examination of government behaviour. Rather than simply assuming that government serves the public interest, Wicksell undertook an assessment of the circumstances in which government provision of public goods would be just and efficient, based on an aggregation of the interests of individuals. Importantly, his analysis explored various voting rules and highlighted the importance of universal franchise. ${ }^{11}$

Subsequent economists like Duncan Black and Anthony Downs explored how competition can lead rational self-interested politicians to act in the interests of the majority, while Schumpeter explored how political leadership, beyond mere representation of the median voter, can be welfare-enhancing when underpinned by periodic voting. ${ }^{12}$ Theorists like William Niskanen and James Buchanan have explored the particular interests of public servants and politicians and the structures in which they operate, and the importance of voters being well-informed. ${ }^{13}$ And seminal work on voting rules and group dynamics has been added by the likes of Kenneth Arrow and Mancur Olson. ${ }^{14}$

While these economists explored the various flaws in democratic models, they also helped build a strong economic argument linking the service of elected politicians with improvements in wellbeing.

So while public servants can sometimes be cynical about the political process, they should gain confidence from the general positive relationship between service in a democracy and wellbeing, notwithstanding difficulties in measuring that wellbeing.

\footnotetext{
11 Wicksell's support for universal franchise was intimately combined with support for requirements for unanimity or near unanimity in government decision-making. (See Wicksell, Knut, 1896 'A New Principle of Just Taxation' (James Buchanan trans) in Richard Musgrave and Alan Peacock (eds), 1967, Classics in the Theory of Public Finance, MacMillan, London.)

12 Black, Duncan 1948 'On the Rationale of Group Decision-making', Journal of Political Economy, 56(1): 23-34; Downs, Anthony 1957 An Economic Theory of Democracy, Harper, New York; Schumpeter, Joseph 1942 Capitalism, Socialism and Democracy, Fifth edition, George Allen and Unwin, London.

13 Niskanen, William 1971 Bureaucracy and Representative Government, Chicago, Aldine; Niskanen, William 2006 'Limiting Government: the Failure of "Starve the Beast"' Cato Journal, 26(3); Buchanan, James 1975 The Limits of Liberty, University of Chicago, Chicago. While not in the field of public finance, the economist and sociologist Max Weber provided seminal contributions on the nature of bureaucracy (see Musgrave, Richard and Peggy Musgrave 1989 Public Finance in Theory and Practice, Fifth edition, McGraw Hill, Singapore: 103). And in the same era as Knut Wicksell, Amilcare Puviani introduced the concept of fiscal illusion (in which there is a disconnect between awareness of government spending and awareness of (eventual) taxation) (see Lindahl, Erik 1919, 'Just Taxation - A Positive Solution' (Elizabeth Henderson trans) in Richard Musgrave and Alan Peacock (eds), 1967, Classics in the Theory of Public Finance, MacMillan, London: 175). The importance of voters being well informed in turn highlights the importance of freedom of political participation, speech and association and a free press.

14 Arrow, Kenneth 1963 Social Choice and Individual Values, Second edition, John Wiley and Sons, New York; Olson, Mancur 1965 The Logic of Collective Action: Public Goods and the Theory of Groups, Harvard, Cambridge, Massachusetts.
} 


\section{Distinguishing elements of wellbeing assists ministerial decision-making}

But public servants do more than just respond to ministers; they use frameworks to advise ministers.

The Treasury's wellbeing framework reminds Treasury staff to explore, and advise ministers of the distinct impacts of policies on various considerations, such as the level and distribution of material consumption, health, and environmental amenity.

The Treasury wellbeing framework identifies five dimensions that directly or indirectly have important implications for wellbeing and are particularly relevant to Treasury. These dimensions are:

- the set of opportunities available to people, including - but not limited to the level of goods and services that can be consumed;

- the distribution of those opportunities across the Australian people;

- the sustainability of those opportunities over time;

- the overall level and allocation of risk borne by individuals and the community; and

- the complexity of the choices facing individuals and the community.

These dimensions cover the key determinants of a person's wellbeing and the distribution of these determinants currently and across generations. They also explicitly recognise risk and complexity given the relevance of these concepts to Treasury's specific responsibilities: advising on macroeconomic policy, well-functioning markets and taxation.

In response to a particular public policy issue, Treasury may identify options that maximise the level of certain opportunities or minimise the overall level of risk or complexity. Treasury may also be able to outline how a policy affects the distribution of opportunities, risk and complexity across the population and over time (noting that the selection of a distributional measure involves normative judgements about what is being distributed, among whom, and whether the measure uses equality or adequacy as a reference point).

In doing this Treasury does not take a corporate position on whether a certain distribution is appropriate, or whether a certain weight should be given to level versus distributional considerations, or whether some types of opportunities are more important than others. Likewise, Treasury does not take a corporate position on the relative weights to apply to the five dimensions of the wellbeing framework. While Treasury advice will at times set out a preferred view based on experience and analysis, decision-making ultimately rests with ministers and 
elected governments, who are called to make value judgements on priorities and trade offs, taking into account community preferences and hence supporting wellbeing.

Nevertheless, the wellbeing framework helps Treasury staff assist ministers to make these value judgements.

For instance, the framework's reference to the level of goods and services for consumption is accompanied by references to various distributional concerns. This reminds staff to consider and outline impacts on both efficiency and distribution - both when the explicit purpose of a policy is to redistribute, and when it is not.

Distributional analysis may reveal that a suite of policies both assists and hinders the same group of people; such a result presumably does not serve distributional goals, whatever those goals may be. ${ }^{15}$ It may reveal that the winners from a certain policy could compensate the losers. It may highlight community views on fairness and other reasons for considering distribution, or it may highlight differences in the distribution for one concept (such as income) but not for another (such as consumption).

So it is not the purpose of the wellbeing framework to enable staff simply to point to options that maximise wellbeing with certainty; this is impossible given the absence of an agreed approach to measuring wellbeing. Rather, the wellbeing framework helps staff set out some dimensions of wellbeing to hopefully help ministers make well-informed value judgements consistent with improving wellbeing.

\section{Treasury draws on powerful, well-established tools to provide thorough analysis}

Treasury's wellbeing framework also requires us to undertake objective and thorough analysis using the best available analytical frameworks.

Treasury faces myriad claims of market failure and needs to draw on economic frameworks to distinguish the well-based claims from the rest. Various economic frameworks are discussed in documents like the Best Practice Regulation Handbook, produced by the Office of Best Practice Regulation in consultation with agencies including Treasury. The Handbook outlines various types of

15 The combined analysis of the tax and transfer system championed by Ian Castles is an example of an approach that allows the coherence of nominally separate systems to be tested (Podger, Andrew 2011 'Ian Castles and the Henry Tax/Transfers Review', Keynote Address - HC Coombs Policy Forum, Australian National University, Canberra). 
market failure, including monopoly and abuse of market power, asymmetric information, externalities, and non-rivalrous or non-excludable goods. It also outlines instances where government may or may not be able to improve the situation. ${ }^{16}$

Treasury can draw on recent economic research on systematic failures in personal decision-making, which applies to the public, but also to public officials. ${ }^{17}$ And Treasury can also draw from literature on types of government failures, including work on fiscal illusion, the theory of second best, and barriers to policy reversal. ${ }^{18}$

Treasury's wellbeing framework also requires staff to gather the best available empirical evidence, in recognition that theory is always more reliable when partnered with empirics. This encompasses such techniques as modelling of distributional impacts over time and studies of fiscal impact. It also includes evidence from research in the relevant policy domains, administrative data demonstrating past experience, and cost benefit analysis, as recommended in the Best Practice Regulation Handbook.

This partnership of robust theory and available empirics can provide considerable assurance that the resulting policy recommendations are consistent with improving wellbeing, notwithstanding the absence of comprehensive wellbeing measures.

\section{The relationship between improving personal wellbeing and societal wellbeing}

A degree of assurance also comes from the nature of individuals in a market-based economy.

The Treasury's approach to wellbeing is cast from the perspective of individuals. As we have said already, Treasury considers that wellbeing primarily reflects a person's substantive freedom to lead a life they have reason to value.

This is an economic approach and is predicated on the idea that, provided that market and government failures are addressed and the government provides a

\footnotetext{
16 Australian Government 2007 Best Practice Regulation Handbook, Office of Best Practice Regulation, Canberra.

17 Tasic, Slavisa 2009 'The Illusion of Regulatory Competence', Critical Review: a Journal of Politics and Society 21(4): 423-436; Glaeser, Edward 2005 'Paternalism and Psychology' Harvard Institute of Economic Research Discussion Paper 2097, Harvard, Cambridge, Massachusetts.

18 Lipsey, Richard and Kelvin Lancaster 1956-57 'The General Theory of Second Best', The Review of Economic Studies, 24(1): 11-32; Hall, Peter 1993 'Policy Paradigms, Social Learning and the State: The Case of Economic Policymaking in Britain, Comparative Politics, 25(3): 275-296.
} 
conducive environment, we should have some confidence that individuals going about their lives will tend to improve their personal wellbeing, the wellbeing of those they care for, and, in part through market transactions, societal wellbeing. (In providing a conducive environment, in general government actions will have implications for the distribution of society's resources across individuals, and for improving equality of opportunity).

This approach is consistent with Australia's democratic and market-based society, and puts the importance of wellbeing measures in context. While better wellbeing measurement will be valuable, we nonetheless have less need for such aggregate measures than do states that specialise in central planning.

\section{Treasury has both broad and specific goals}

Treasury needs to regularly assess its success or otherwise in improving wellbeing and in being an effective central policy agency with whole-ofgovernment responsibilities, notwithstanding the difficulties in measuring such success. However, when considering Treasury's need for wellbeing measurement, it is also important to note that Treasury has been tasked with specific, more measurable, goals alongside its broad wellbeing goal.

These specific goals include the achievement of strong, sustainable economic growth, the efficient provision of Commonwealth payments to the State and Territory governments, the preparation of documents in compliance with the Charter of Budget Honesty, effective taxation and retirement income arrangements, competitive and efficient markets, a reduced regulatory burden on business, and improved housing supply and affordability.

Success against each of these goals can be measured more readily than success against the broad wellbeing goal. And, in Treasury's view, success against each of these specific goals would represent an important contribution to improving wellbeing.

\section{A measured approach to new measures}

So while efforts to improve the measurement of wellbeing are important, public policy agencies like Treasury can nonetheless carry out their responsibilities in the absence of a fully agreed, and comprehensive, approach to wellbeing measurement.

Given this, we should take a dispassionate approach when looking at efforts to improve the measurement of wellbeing. We can weigh the potential benefits of efforts to improve wellbeing measures against the costs of those efforts and the risks that resulting measures might be flawed, misused or go unused. 


\section{Conclusion}

Australia is at the forefront of wellbeing measurement. The Measures of Australia's Progress project of the Australian Bureau of Statistics was ahead of its time, and continues to provide an insightful, wide-ranging and balanced dashboard of important indicators to assist public debate and understanding. This dashboard approach is the best way to grapple with perhaps the most important and challenging measurement question there can be.

It is important that we continue to counter misuse of existing measures, strive to improve individual measures, and promote consideration of a broad array of measures. There is much to gain from such efforts.

That said, it is important to note that, in the absence of a widely agreed approach to wellbeing measurement, public service and government decision-making are not blind. They continue to be guided by the democratic process, economic theory, and conscientious analysis. This is the context for Treasury's wellbeing framework, and it leaves Treasury as an eager, rather than dependent, user of wellbeing measures.

In undertaking its mission Treasury takes a broad view of wellbeing as primarily reflecting a person's substantive freedom to lead a life they have reason to value.

This view encompasses more than is directly captured by commonly used measures of economic activity. It gives prominence to respecting the informed preferences of individuals, while allowing scope for broader social actions and choices. It is open to both subjective and objective notions of wellbeing, and to concerns for outcomes and consequences as well as for rights and liberties.

Treasury brings a whole-of-economy approach to providing advice to government based on an objective and thorough analysis of options. To facilitate that analysis, we have identified five dimensions that directly or indirectly have important implications for wellbeing and are particularly relevant to Treasury. These dimensions are:

- The set of opportunities available to people. This includes not only the level of goods and services that can be consumed, but good health and environmental amenity, leisure and intangibles such as personal and social activities, community participation and political rights and freedoms.

- The distribution of those opportunities across the Australian people. In particular, that all Australians have the opportunity to lead a fulfilling life and participate meaningfully in society.

- The sustainability of those opportunities available over time. In particular, consideration of whether the productive base needed to generate opportunities 
(the total stock of capital, including human, physical, social and natural assets) is maintained or enhanced for current and future generations.

- The overall level and allocation of risk borne by individuals and the community. This includes a concern for the ability, and inability, of individuals to manage the level and nature of the risks they face.

- The complexity of the choices facing individuals and the community. Our concerns include the costs of dealing with unwanted complexity, the transparency of government and the ability of individuals and the community to make choices and trade-offs that better match their preferences.

These dimensions reinforce our conviction that trade-offs matter deeply, both between and within dimensions. The dimensions do not provide a simple checklist: rather their consideration provides the broad context for the use of the best available economic and other analytical frameworks, evidence and measures.

\section{References}

Arrow, Kenneth (1963). Social Choice and Individual Values, Second edition, John Wiley and Sons, New York.

Australian Government (1998). A Guide to Regulation, Second edition, Office of Regulation Review, Canberra.

Australian Government (2007). Best Practice Regulation Handbook, Office of Best Practice Regulation, Canberra.

Black, Duncan (1948). 'On the Rationale of Group Decision-making', Journal of Political Economy, 56(1): 23-34.

Buchanan, James (1975). The Limits of Liberty, University of Chicago, Chicago

Downs, Anthony (1957). An Economic Theory of Democracy, Harper, New York

Fleurbaey, Marc (2009). 'Beyond GDP: The Quest for a Measure of Social Welfare', Journal of Economic Literature, 47(4): 10291075.

Glaeser, Edward (2005). 'Paternalism and Psychology', Harvard Institute of Economic Research Discussion Paper 2097, Harvard, Cambridge, Massachusetts.

Gorecki, Stephanie, David Gruen and Shane Johnson (2011). 'Measuring Wellbeing in Theory and Practice', Treasury Working Paper No. 2011-02, Canberra. 
Gruen, David and Joanne Wilkie (2009). 'New Paradigms to Measure Progress', Economic Roundup, Issue 4: 1-9.

Hall, Peter (1993). 'Policy Paradigms, Social Learning and the State: The Case of Economic Policymaking in Britain', Comparative Politics, 25(3): 275-296.

Inglehart, Ronald, Robert Foa, Christopher Peterson and Christian Welzel (2008). 'Development, Freedom, and Rising Happiness: A Global Perspective (1981-2007)', Perspectives on Psychological Science 3(4): 264-285.

Inglehart, Richard and Hans-Dieter Klingemann (2000). 'Genes, culture, democracy and happiness', in Ed Diener and Eunkook (eds) Subjective Well-being Across Cultures, MIT Press, Cambridge, Massachusetts.

Kelly, James and Stephanie Gorecki (2012). 'Treasury's Wellbeing Framework' Economic Roundup, Issue 3: 27-64.

Lindahl, Erik (1919). 'Just Taxation - A Positive Solution' (Elizabeth Henderson trans), in Richard Musgrave and Alan Peacock (eds) 1967 Classics in the Theory of Public Finance, MacMillan, London.

Lipsey, Richard and Kelvin Lancaster (1956-57). 'The General Theory of Second Best', The Review of Economic Studies, 24(1): 11-32.

Niskanen, William (1971). Bureaucracy and Representative Government, Chicago, Aldine.

Niskanen, William (2006). 'Limiting Government: The Failure of "Starve the Beast"', Cato Journal, 26(3).

Olson, Mancur (1965). The Logic of Collective Action: Public Goods and the Theory of Groups, Harvard, Cambridge, Massachusetts.

Podger, Andrew (2011) 'Ian Castles and the Henry Tax/Transfers Review', Keynote Address - HC Coombs Policy Forum, Australian National University, Canberra.

Sen, Amartya (1999). Development as Freedom, Oxford University Press, Oxford.

Schumpeter, Joseph (1942). Capitalism, Socialism and Democracy, Fifth edition, George Allen and Unwin, London.

Stiglitz, Joseph, Amartya Sen and Jean-Paul Fitoussi (2009). 'Report by the Commission on the Measurement of Economic Performance and Social Progress', Commission on the Measurement of Economic Performance and Social Progress.

Tasic, Slavisa (2009). 'The Illusion of Regulatory Competence', Critical Review: A Journal of Politics and Society 21(4): 423-436. 
Treasury (1964). 'The Meaning and Measurement of Economic Growth', Supplement to the Treasury Economic Bulletin, November, Canberra.

Treasury (1973). 'Economic Growth: Is It Worth Having?' Treasury Economic Paper No. 2, Canberra.

Treasury (2004), 'Policy advice and Treasury's wellbeing framework', Economic Roundup, Winter, Canberra.

Treasury (2011). Treasury Strategic Framework, Canberra. 